This document is the accepted manuscript version of the following article:

Loran, C., Kienast, F., \& Bürgi, M. (2018). Change and persistence: exploring the driving forces of long-term forest cover dynamics in the Swiss lowlands. European Journal of Forest Research, 137(5), 693-706. https://doi.org/10.1007/s10342-018-1134-z

Submitted to: European Journal of Forest Research

\title{
Change and persistence - Exploring the driving forces of long-term forest cover dynamics in the Swiss lowlands
}

\author{
Christin Loran ${ }^{a *}$, Felix Kienast $^{\mathrm{a}}$, Matthias Bürgi ${ }^{\mathrm{a}}$
}

Address:

a WSL Swiss Federal Institute for Forest, Snow and Landscape Research, Zürcherstrasse 111, 8903 Birmensdorf, Switzerland

*Corresponding author:

Tel: $\quad$ +41447392817 (Phone)

Fax: $\quad$ +41447392215 (Fax)

Mail: christin.loran@wsl.ch

Manuscript word count: 7353

Acknowledgments

We gratefully acknowledge the support of the Swiss National Science Foundation (SNSF) in the project Forest dynamics in Switzerland (FORDYNCH)-pattern, driving forces and ecological implications (Grant No. 200021-143242). We would like to thank Christian Ginzler and Susette Haegi for their support with the preparation of the forest cover data. Thanks also go to Sarah Radford, who kindly improved the English of this manuscript. 


\section{Abstract}

By the end of the $20^{\text {th }}$ century, the forest cover over most of Europe had stabilized or was increasing after many decades of decline. Persistence and change in forest cover are driven by complex human-environmental interactions and feedback loops operating on different temporal and spatial scales. A promising method to detect these complex interactions between driving forces is a qualitative approach based on historical documents. In the first step of this study, forest cover was reconstructed based on historical and contemporary maps of the Canton of Zurich at seven different points in time between 1664 and 2000. Secondly, causal chains of drivers were constructed based on historical document analysis, in order to investigate whether forest cover was stable or if any compensating mechanisms in place were reducing the net changes. While the overall net forest cover remained considerably persistent in the Canton of Zurich throughout the 336-year study period, major gross forest cover losses and gains were detected during certain periods. Major deforestation events occurred during times of crisis, e.g., at times of economic or political crisis. By contrast, the strong persistence of net forest cover was mainly a consequence of the Forest Police Law, but can also be attributed to intensive land use. The law prohibits deforestation in general and intensive land use is preventing the kind of natural reforestation occurring in other regions, e.g., the Swiss Alps. These empirical findings shed light on the relevance of a high degree of political and economic stability in terms of maintaining landscape persistence. These insights into the driving forces of forest cover change and persistence can contribute to protecting and managing valuable landscapes in a rapidly changing world.

Keywords: forest cover change, forest cover persistence, driving forces, long-term study, Switzerland 


\section{Introduction}

Forests cover around $31 \%$ of the global land surface, but their extent is subject to constant change. It is estimated that global forest cover has decreased by nearly $50 \%$ of the total forest area in the past 5000 years to just under four billion hectares in 2015 , mainly due to the expansion of agricultural land and the unsustainable exploitation of forest resources (FAO 2016). This change has resulted in serious consequences for a wide range of ecosystem services, e.g., climate regulation, carbon storage, water supply and biodiversity (Foley et al. 2005). In temperate and boreal climate zones, deforestation slowed or reversed in the late $19^{\text {th }}$ and $20^{\text {th }}$ centuries. By the end of the $20^{\text {th }}$ century, most of the forest cover in Europe was either stable or increasing (FAO 2016). Despite this increasing trend, European forests were simultaneously identified as being among the most fragmented in the world, due to the strong anthropogenic imprint on the landscape (Wade et al. 2003). Fragmentation is a physical process of dividing habitats, ecosystems or land-use types into smaller parcels (Andrén 1994; Llausàs and Nogué 2012). The degree of forest fragmentation does not necessarily depend on the amount of forest cover, as it can develop largely independent of forest gain or loss (Matthews et al. 2000). Fragmentation may be caused by various activities or events, e.g., road constructions, logging, conversion to agriculture or wildfires (Jaeger et al. 2007). Species in such fragmented habitats tend to be at higher risk of decline or even local extinction, resulting in an immediate and/or time-delayed loss of biodiversity (Krauss et al. 2010). Quantitative information about forest fragmentation can therefore serve as an essential indicator for assessing forest quality. In order to manage forest cover changes in a more sustainable way, it is essential to increase our knowledge of the driving forces behind forest cover change and persistence.

The driving forces behind forest and overall land cover change are the result of a complex interplay between various natural conditions and anthropogenic processes operating to different temporal and spatial extents (Meyfroidt 2015; Plieninger et al. 2016). They are often categorized as socioeconomic, political, technological, cultural or natural drivers (Brandt et al. 1999; Hersperger and Bürgi 2009), which operate on various scales, i.e., from the local level with a direct impact to the national or even global levels, often with a more indirect impact (Geist and Lambin 2002). Furthermore, these drivers can act remotely in space and time in terms of 
their observed impacts (Serneels and Lambin 2001); this has been recently explicitly addressed by the concept of teleconnections and telecoupling (Liu et al. 2014). Causal analysis is a convenient method of determining such indirect drivers (Efroymson et al. 2016). Arranging the identified drivers in causal chains - where each step links a cause or combination of causes with its direct outcome, the latter being a direct cause of the subsequent outcome (Meyfroidt 2015) - provides a synoptic overview of the complex interplay between them.

Switzerland is a country that has undergone opposing trends in forest cover over the past decades. Its mountainous areas have experienced a strong expansion in forest cover, whereas in the lowlands, forest cover remained almost stable between 1850 and 2000, i.e., any small losses and gains almost canceled each other out (Loran et al. 2016). While these changes and their drivers in the mountainous regions of Switzerland have been the focus of past research (Gellrich et al. 2007; Gellrich and Zimmermann 2007; Loran et al. 2017; Rutherford 2006), little is known about the processes leading to the persistence of forest cover in the lowlands. For the Canton of Zurich, which is the focus of this study due to the better availability of source material, a series of local publications have been published on forest and landscape dynamics. These publications include studies on the drivers of changes in forest use in the northern part of the canton (Bürgi 1999), the driving forces of forest management throughout the whole of the Canton of Zurich (Bürgi and Schuler 2003) as well as on the drivers of landscape change in the Limmat Valley in the region on the border between the Canton of Zurich and Aargau (Hersperger and Bürgi 2007). However, the following questions remain unanswered: What is driving forest persistence over such long timespans in the Swiss lowlands? Is forest cover stable, or are there compensating mechanisms in place that are reducing the net changes? Our overarching goal was to increase knowledge about the drivers of forest cover change and persistence, which is essential for the better management of our future landscapes. Specifically, the following research questions were addressed:

1) How has forest cover changed in the Canton of Zurich in the last few centuries?

2) What was the impact of these changes on forest fragmentation?

3) What were the major drivers of the observed changes and persistence in forest cover? 


\section{Material and Methods}

In order to answer the research questions, the net and gross changes in forest cover were quantified based on a topographic map comparison. This spatially-explicit data source enabled us to identify changes in continuously forested areas and newly developed forest cover, as well as to see how forest cover fragmentation has developed over time. The effect of the range of relevant drivers on these dynamics was then analyzed based on detailed analyses of the 10 largest patches of forest gain and loss over the past 150 years.

\subsection{Study area - the Canton of Zurich}

The Canton of Zurich, covering an area of $1,728.9 \mathrm{~km}^{2}$ in the northern part of Switzerland (SFSO 2014), is the most densely populated canton of Switzerland, with 871 inhabitants per square kilometer (Statistical Office Canton of Zurich 2016). Its capital, Zurich, is the largest city in Switzerland. Its high population density is reflected by its land cover, as $30 \%$ is covered by settlement land. Besides agricultural land use (42\%), forest also covers a substantial area, covering $22 \%$ of the canton. The amount of forest cover has been relatively stable since around the $13^{\text {th }}$ century (Walser 1896), in contrast to mountainous areas of Switzerland, which have experienced major changes in forest cover over the past 150 years (Loran et al. 2016). The three main tree species are spruce (38\%), beech (23\%) and fir (12\%). The forested areas of the Canton of Zurich are mostly privately owned (47\%) or are owned by municipalities (33\%). Only $12 \%$ is owned by corporations, $7 \%$ is owned by the canton and $1 \%$ is federal forest (Amt für Landschaft und Natur 2017).

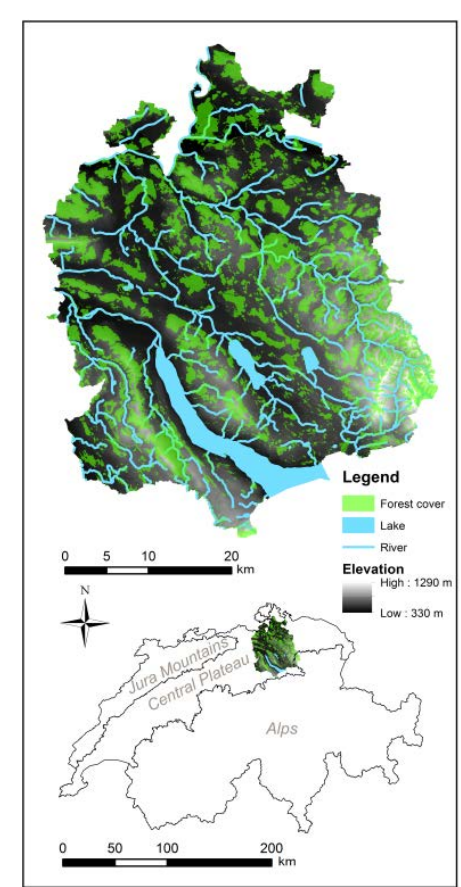

Fig. 1: Case study area Canton Zurich and the forest cover in the year 2000. 


\subsection{Data - historical and contemporary topographic maps}

In order to quantify the proportion of forest cover in the Canton of Zurich, we reconstructed the region's forest cover over the past 336 years based on time series maps (Tab. 1). These maps (Fig. 2) are available from the Swiss Federal Institute of Forest, Snow and Landscape Research (WSL) and most of the map series can be viewed online (Swisstopo 2015).

Tab. 1: Historical and contemporary topographic maps which served as a source for the reconstruction of forest cover in Canton Zurich.

\begin{tabular}{|c|c|c|c|c|c|}
\hline Map & Year & $\begin{array}{l}\text { Time period (map } \\
\text { sheets published) }\end{array}$ & Scale & Mapping method & $\begin{array}{l}\text { Representation } \\
\text { of forest }\end{array}$ \\
\hline Gyger Map & 1664 & 1664 & $1: 32,000$ & $\begin{array}{l}\text { created without standard geodetic } \\
\text { methods, based on detailed terrain } \\
\text { observations and estimations of } \\
\text { distances }\end{array}$ & black circles \\
\hline $\begin{array}{l}\text { Dufour } \\
\text { Original Survey } \\
\text { Map }\end{array}$ & 1850 & $1841-1854$ & $1: 25,000$ & based on triangulation & $\begin{array}{l}\text { green filled } \\
\text { areas }\end{array}$ \\
\hline Siegfried Map & 1880 & $1878-1889$ & $1: 25,000$ & based on triangulation & black circles \\
\hline Siegfried Map & 1910 & $1896-1910$ & $1: 25,000$ & based on triangulation & black circles \\
\hline Siegfried Map & 1940 & $1932-1940$ & $1: 25,000$ & based on triangulation & black circles \\
\hline National Map & 1970 & $1970-1972$ & $1: 25,000$ & based on aerial images & $\begin{array}{l}\text { green filled } \\
\text { areas }\end{array}$ \\
\hline $\begin{array}{l}\text { Vector } 25 \\
\text { National Map }\end{array}$ & 2000 & 1995-2000 & $1: 25,000$ & based on aerial images & $\begin{array}{l}\text { green filled } \\
\text { areas }\end{array}$ \\
\hline
\end{tabular}

The Gyger Map was the first map to cover the whole of the Canton of Zurich. The map was published in 1664 in 56 map sheets and in 1667 as a complete painting, with the dimensions of $226 \times 220 \mathrm{~cm}$. The map was named after its creator, Hans Conrad Gyger, who lived in Zurich from 1599 to 1676 and was a painter, mathematician and topographer (Walser 1896; Wyder 2006). He worked for 38 years on the Gyger Map, which is considered to be the precursor of the modern colored relief map and is an important historical source for the Canton of Zurich. It was the most magnificent cartographical work made in Switzerland during that time (Wyder 2006). The forest cover is represented by areas of half or full circles with a black line boundary. The Dufour Original Survey Map, covering the whole of Switzerland, was published between 1834 and 1863 at a scale of 1:25,000 (Jura Mountains and Central Plateau) and 1:50,000 (Alps). 
These map sheets are the drawings upon which the Dufour Map, published between 1845 and 1865 at a scale of 1:100,000 (Swisstopo 2015), was based. Guillaume-Henri Dufour collaborated with scientists, topographers and copperplate engravers to create this topographic map. Field measurements were based on the traditional technique of graphical triangulation on ordinance survey maps (Imhof 1927). The forest cover is represented by green filled areas.

The Siegfried Maps, covering the whole of Switzerland, were published between 1870 and 1949 at a scale of 1:25,000. Herman Siegfried proposed the publication of the Dufour Original Survey Maps at their original scale in around 1867/68. Only a few maps covering the Central Plateau could be published after minor changes, while most of the map sheets required major revisions as they were several decades old (Grosjean 1996). The forest cover is represented by small black circle-like symbols with thin black lines indicating the forest boundaries.

The National Map 1:25,000 is a topographic map of Switzerland representing areas of traffic and settlements, as well as the country's topography and vegetation. It was produced after the Siegfried maps. The map content is updated according to a regular six-year cycle, dividing Switzerland into six sectors. The National Map covering the area of Zurich is based on revisions made to the National Map in the cycle between 1966 and 1970. It was based on aerial images acquired between 1962 and 1968, with an average scale of 1:27,000. The National Map $1: 25,000$ is published in analog format, as a printed map and in digital format. The forest cover is represented by light green polygons with dark green borders. Where there was no clear forest boundary, the dark green border was replaced by small green circle symbols. Open forest is represented by small green circle symbols.

In 1995, Swisstopo initialized the production of a 1:25,000 vector dataset. Vector25 is a digital topographic landscape model based on the analog National Map 1:25,000. It was designed so that the content of the National Map could be used in geographic information systems (GIS). The forest cover is represented by closed-forest polygons and open-forest polygons. 

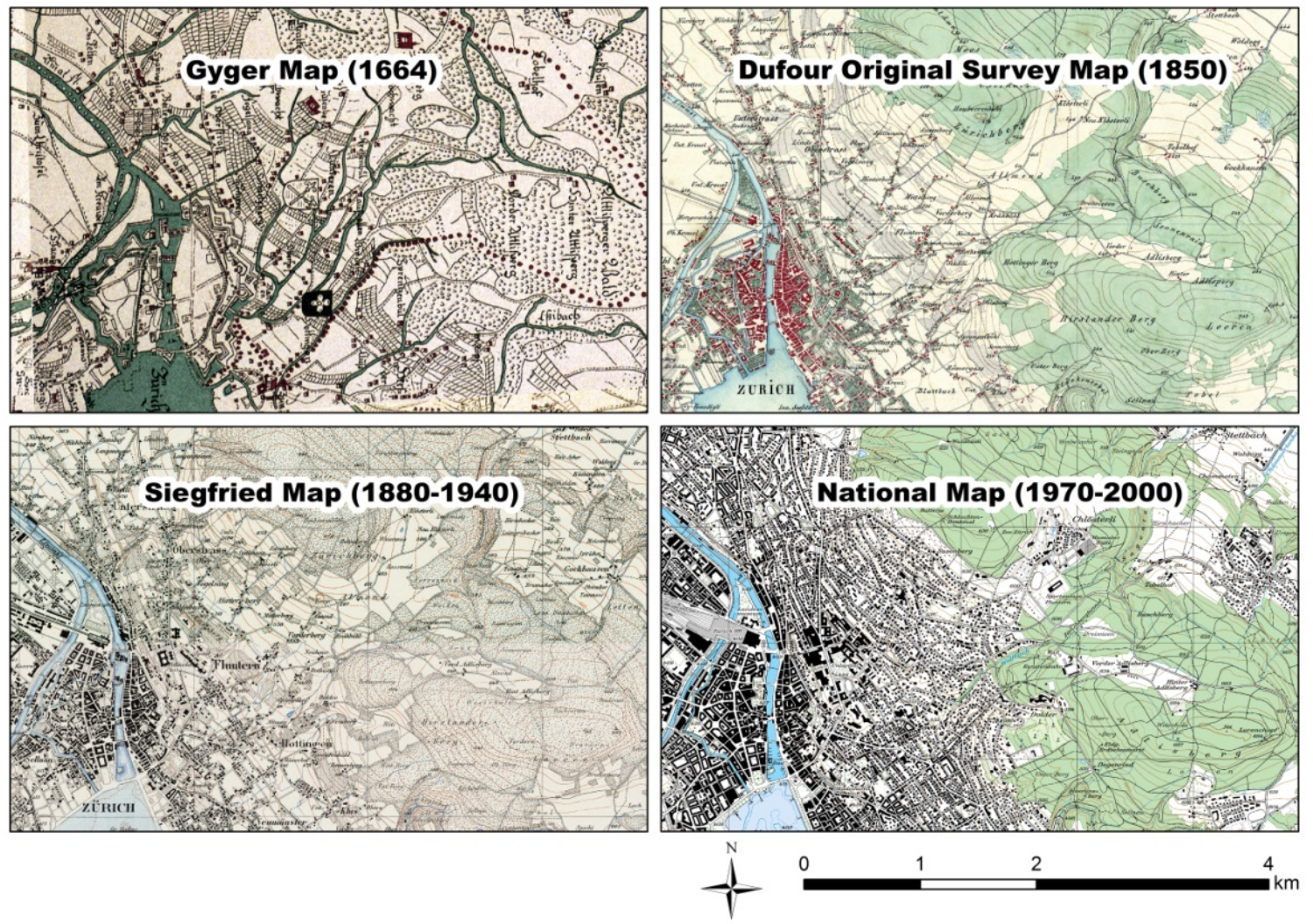

Fig. 2: Time series of historical and contemporary maps, representing part of the City of Zurich and the northern end of Lake Zurich. Forest cover is represented by circle-like symbols (Gyger and Siegfried Map) or with green filled areas (Dufour Original Survey and National Map)

In order to quantify the forest cover and its dynamics at seven different points in time in Switzerland, forest trajectories were reconstructed based on the maps presented above. Whereas the Gyger map sheets were published in 1664, the Dufour, Siegfried and National maps were drawn and published during repeated mapping campaigns. Due to the duration of these mapping campaigns, maps covering all of Zurich are based on map sheets drawn over the course of several years. Therefore, the respective points in time of 1850, 1880, 1910, 1940, 1970 and 2000 refer to the mapping campaigns mentioned above in the map description.

An assessment of the accuracy and comparability of the maps used in this study was conducted by Loran et al. (under revision). Their study revealed that the old maps have remained highly accurate since 1850 (Dufour Original Survey Map). Only the Gyger Map from 1664 showed some substantial distortion and a different level of generalization of forest cover in comparison to the 
later maps. Therefore, the Gyger Map was used to calculate the total forest cover in the Canton of Zurich in 1664, which is valuable information in terms of understanding long-term changes in gross forest cover; however, it had to be excluded from a spatially explicit comparison (e.g., net change, fragmentation).

\subsection{Determining change and persistence in forest cover}

In order to quantify the amount of forest cover for each time step and how it has changed during the five time periods between 1850 and 2000 (30-year intervals), the amount of forest cover was obtained from the maps in polygons, by manually digitizing them from the maps made between 1664 and 1940. For the 1970 map series, a semi-automated feature extraction procedure based on color separation and morphological processing was applied, followed by manual correction (Kaim et al. 2016). The forest cover for the year 2000 was available in polygon format from Swisstopo. The digitization and calculation of forest cover was performed using ArcGIS 10.2. Additionally, road and railway infrastructure was digitized within the forest patches for all of the maps, in order to assess the level of fragmentation.

Considering the expansion of road networks across the globe, this infrastructure provides a useful proxy indicator of habitat fragmentation and degradation. For example, roads can form physical barriers to the movement of wildlife (Matthews et al. 2000). Due to the fact that information on road width was missing from the historical maps, we used a standard width of 10 meters for all roads and railway lines for all of the maps. The fragmentation of forest patches was calculated in FRAGSTATS v4.2.1 for six points in time $(1850,1880,1910,1940,1970$ and 2000), both with and without the effect of road and railway infrastructure. For each time point, we calculated the number of patches (NP), the total core area (TCA) and the fractal dimension index (FRAC) of the forested areas. The FRAC is a shape index based on perimeter-area relationships, which quantifies the degree of complexity across a range of spatial scales (patch sizes). The FRAC value can range between one - shapes with very simple perimeters - and two shapes with highly convoluted perimeters. The TCA represents the aggregated area in all forest patches greater than the specific depth-of-edge distance from the perimeter. The size of the TCA is decisive for the development of interior conditions beneath the canopy of a forest patch. 
We set the distance value to 50 meters, because the effect of agricultural land on the microclimate can extend for over 50 meters into a forest (Cunningham et al. 2015; Murcia 1995).

\subsection{Exploring the driving forces of forest cover change and persistence}

In order to identify the various drivers of forest cover change and persistence, which we arranged in causal chains, we mainly studied old forest management plans. These plans are available in the state archive of the Canton of Zurich. The plans date back to the beginning of the $19^{\text {th }}$ century and are a unique source for the reconstruction of forest history (Bürgi 1999). They were written by the forester of the respective forestry district and contain a wealth of information - e.g., the size and location of the forest and how it has changed, a description of the current management and suggestions for the future management of municipal forests. Another important source was the secondary literature (e.g., a compilation of 650 years of forest history from the Canton of Zurich by Weisz et al. (1983)), which provided detailed information about the development of forest cover and its drivers. The relevant literature is cited in the results section, together with the identified drivers.

An in-depth qualitative assessment of the drivers was carried out for each of the 10 largest spatially continuous areas of forest loss and gain occurring during any of the 30 -year periods in the Canton of Zurich. In order to systematically present the results of these 20 cases, the drivers were assigned to one of five categories: socioeconomic, political, natural, technological or cultural drivers, as proposed by Bürgi et al. (2004). Furthermore, we assembled the drivers into causal chains to provide a synoptic picture of their interplay. Deforestation and afforestation are the end points of these chains. 


\section{Results}

\subsection{Historical development of forest cover in the Canton of Zurich}

The total amount of forest cover remained remarkably stable over the whole study period, with 50,580 ha covered by forests in 1664 compared to 50,668 ha in 2000 (Fig. 3). However, small changes were detected in the single study periods. While the forest cover increased during the period between 1664 and 1850, it decreased during the period between 1850 and 1880 and remained nearly stable between 1880 and 1940. Between 1940 and 1970, there was a second decrease before the forest cover increased during the last period (between 1970 and 2000). The amount of continuous forest cover decreased constantly over the whole study period due to the constant turnover of forest area; this was partly compensated for by new afforestation. For the first period between 1664 and 1850, no distinction was made between new and continuous forest cover because the distortions in the Gyger Map from 1664 did not facilitate accurate spatial comparison. Therefore, only the amount of forest cover was calculated. The spatial distribution of continuous and new forest cover in the Canton of Zurich is presented in Fig. S1 (supplementary material).

New forest cover (after 1850)

Continuous forest cover (since 1850)

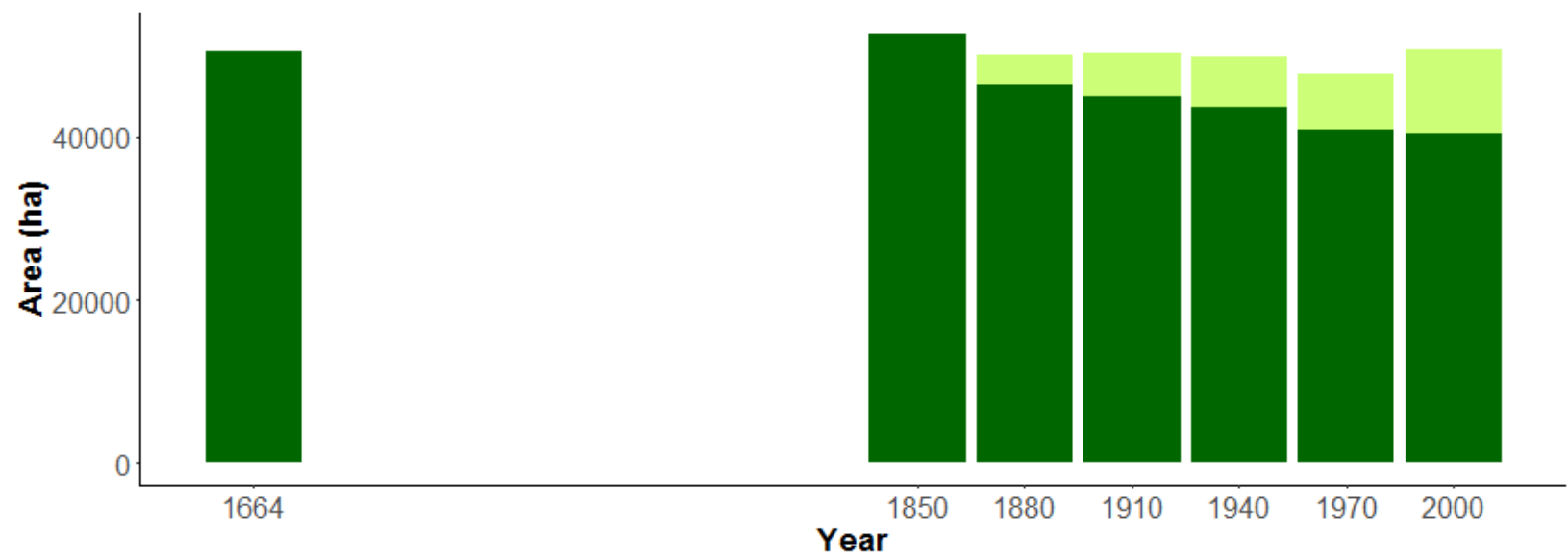

Fig. 3: Changes in continuous and new forest cover in Canton Zurich (1664 - 2000). 
The occurrence of deforestation and afforestation events within a single period cause relatively large gross changes, while the overall net change is much smaller (Fig. 4). The level of both deforestation and afforestation vary between the different periods. The highest gross and net change occurred during the two periods between 1850 and 1880 and between 1940 and 1970 . The largest single deforestation events occurred during the same periods (Tab. 2). In contrast, the largest afforestation events took place during the first two study periods of 1850 to 1880 and 1880 to 1910 . Overall, the majority of afforestation and deforestation events cover areas smaller than five hectare.

Fig. 4: Net and gross change of forest cover in Canton Zurich for five periods between 1850 and 2000. Bars illustrate the gross change in forest cover and the filled part of the bars represents the net changes in forest area.

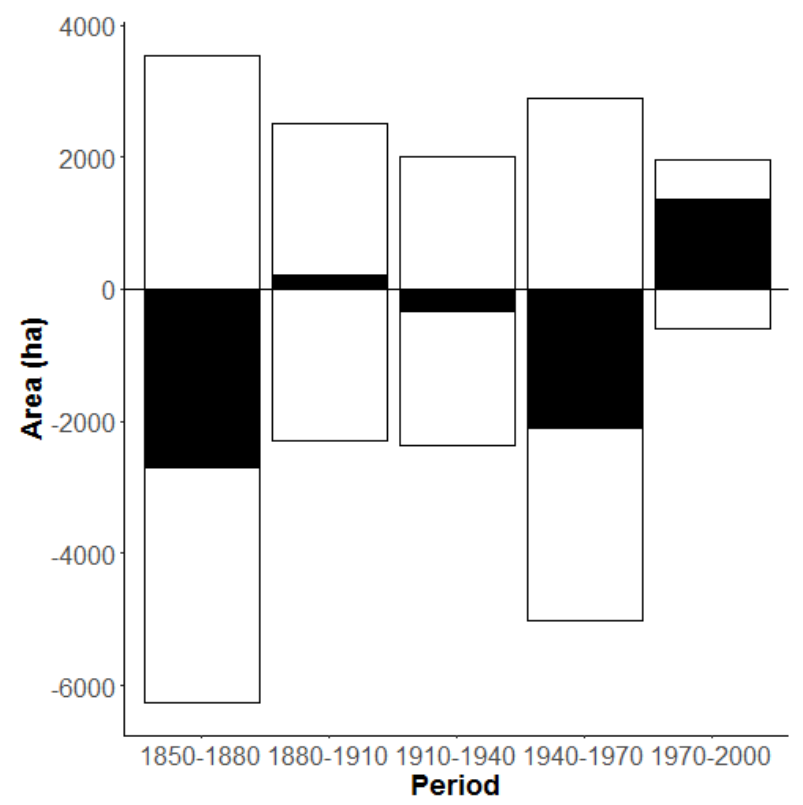

Focusing on the fragmentation of forest cover, the results show that road and railway infrastructure in forest areas more than doubled between $1850\left(1.94 \mathrm{~km}^{2}\right)$ and $2000\left(4.69 \mathrm{~km}^{2}\right)$, which is still less than one percent of the total forest area (Tab. S1, supplementary material). The total core area within single forest patches decreased until 1970 due to an increase in infrastructure (Fig. 5A). Between 1970 and 2000, the core area increased slightly, which can be attributed to an overall increase in forest cover during that period (Fig. 4). A calculation of fragmentation that excluded infrastructure revealed a different picture. In this case, the core area varies over time according to the total amount of total forest cover (Fig. 3), e.g., a decrease in overall forest cover triggers a decrease in the core area, and vice versa. A similar development could be observed in terms of the number of forest patches (Fig. 5B), which changes over time according to the total forest cover. Overall, infrastructure caused a decrease in the total core area and an increase in the number of patches. In contrast, the complexity of 
the forest shapes, which is represented by the FRAC value in Fig. 5C, was relatively stable over the whole study period.
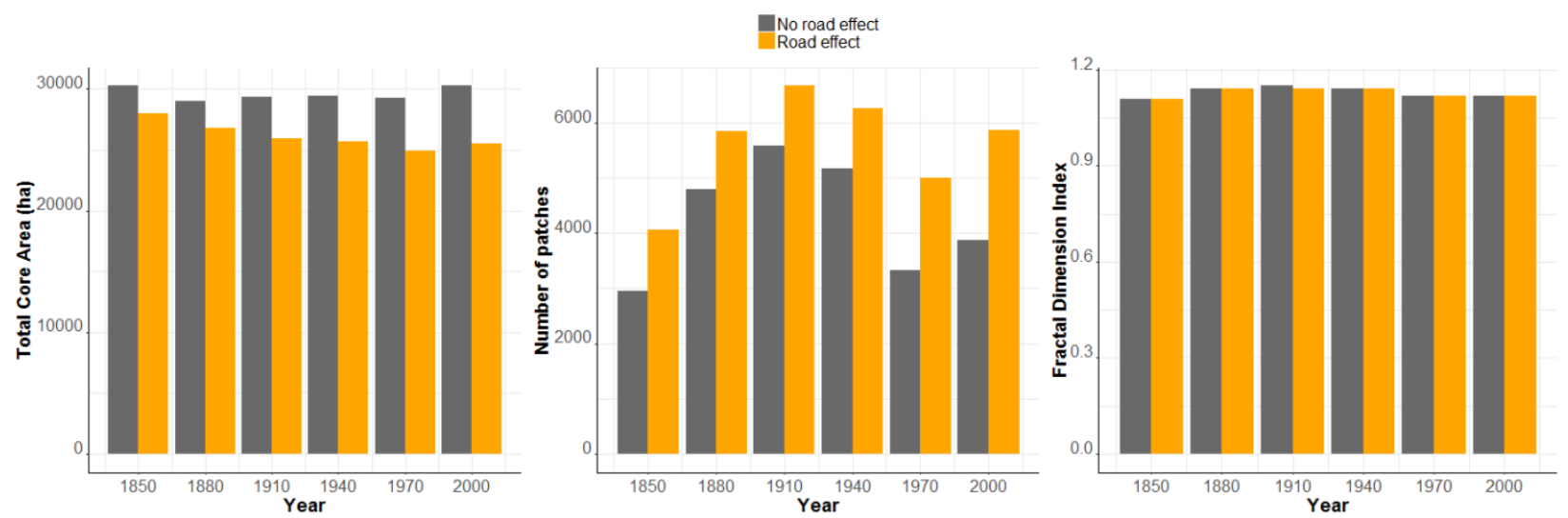

Fig. 5: A) Total core area of forest patches over the 150-year study period with an edge depth of $50 \mathrm{~m}$. B) Number of forest patches with and without road effect. C) Fractal dimension index for forest cover in Canton Zurich (1850-2000), with and without road effect.

Tab. 2: Number and size of afforestation and deforestation events in Canton Zurich (1850-2000).

\begin{tabular}{|c|c|c|c|c|c|c|c|c|c|c|}
\hline \multicolumn{11}{|c|}{ Afforestation Canton Zurich } \\
\hline & \multicolumn{2}{|c|}{$1850-1880$} & \multicolumn{2}{|c|}{$1880-1910$} & \multicolumn{2}{|c|}{$1910-1940$} & \multicolumn{2}{|c|}{$1940-1970$} & \multicolumn{2}{|c|}{$1970-2000$} \\
\hline $\begin{array}{c}\text { Class } \\
\text { (ha) }\end{array}$ & Counts & $\begin{array}{c}\text { Area } \\
\text { (ha) }\end{array}$ & Counts & $\begin{array}{c}\text { Area } \\
\text { (ha) }\end{array}$ & Counts & $\begin{array}{c}\text { Area } \\
\text { (ha) }\end{array}$ & Counts & $\begin{array}{c}\text { Area } \\
\text { (ha) }\end{array}$ & Counts & $\begin{array}{c}\text { Area } \\
\text { (ha) }\end{array}$ \\
\hline $0-5$ & 27389 & 3007.2 & 31147 & 2263.1 & 42697 & 1940.4 & 25444 & 2790.6 & 45666 & 1881.0 \\
\hline $5-10$ & 25 & 161.0 & 12 & 82.1 & 6 & 37.7 & 11 & 76.1 & 10 & 65.9 \\
\hline $10-15$ & 13 & 158.3 & 5 & 60.0 & 2 & 28.3 & 1 & 10.8 & - & - \\
\hline $15-20$ & 6 & 102.2 & - & - & - & - & 1 & 15.7 & 1 & 15.4 \\
\hline $20-25$ & - & - & 3 & 63.1 & - & - & - & - & - & - \\
\hline $25-30$ & 3 & 80.7 & - & - & - & - & - & - & - & - \\
\hline $30-35$ & - & - & - & - & - & - & - & - & - & - \\
\hline $35-40$ & 1 & 37.4 & - & - & - & - & - & - & - & - \\
\hline $40-45$ & - & - & 1 & 40.3 & - & - & - & - & - & - \\
\hline \multicolumn{11}{|c|}{ Deforestation Canton Zurich } \\
\hline & \multicolumn{2}{|c|}{$1850-1880$} & \multicolumn{2}{|c|}{$1880-1910$} & \multicolumn{2}{|c|}{$1910-1940$} & \multicolumn{2}{|c|}{$1940-1970$} & \multicolumn{2}{|c|}{$1970-2000$} \\
\hline $\begin{array}{c}\text { Class } \\
\text { (ha) }\end{array}$ & Counts & $\begin{array}{c}\text { Area } \\
\text { (ha) }\end{array}$ & Counts & $\begin{array}{c}\text { Area } \\
\text { (ha) }\end{array}$ & Counts & $\begin{array}{c}\text { Area } \\
\text { (ha) }\end{array}$ & Counts & $\begin{array}{r}\text { Area } \\
\text { (ha) }\end{array}$ & Counts & $\begin{array}{r}\text { Area } \\
\text { (ha) }\end{array}$ \\
\hline $0-5$ & 25533 & 4998.1 & 30368 & 2064.9 & 43021 & 2118.3 & 27394 & 4369.3 & 32192 & 571.9 \\
\hline $5-10$ & 82 & 550.9 & 15 & 107.5 & 13 & 90.0 & 36 & 254.6 & 3 & 21.2 \\
\hline $10-15$ & 18 & 217.3 & 6 & 75.1 & 6 & 70.2 & 8 & 94.0 & 1 & 11.7 \\
\hline $15-20$ & 5 & 84.0 & 2 & 35.1 & 3 & 54.1 & 1 & 15.3 & - & - \\
\hline $20-25$ & 3 & 66.0 & - & - & 1 & 22.5 & 3 & 67.5 & - & - \\
\hline $25-30$ & 2 & 57.7 & - & - & - & - & - & - & - & - \\
\hline $30-35$ & - & - & - & - & - & - & - & - & - & - \\
\hline $35-40$ & 1 & 35.7 & - & - & - & - & - & - & - & - \\
\hline $40-45$ & 2 & 82.9 & - & - & - & - & 1 & 44.9 & - & - \\
\hline$>45$ & 2 & 167.5 & - & - & - & - & 1 & 162.8 & - & - \\
\hline
\end{tabular}




\subsection{Drivers of forest cover change and persistence}

\subsubsection{Drivers of afforestation}

The biggest increases in forest area recorded during the last 150 years were due to afforestation for the establishment and the expansion of state forest at the beginning of the $19^{\text {th }}$ century., i.e., the Tössstock state forest (afforestation 1 and 7 in Fig. 6 - the subsequent numbers provided in parentheses all refer to Fig. 6), which now covers an area of 845 ha (Office of Landscape, Agriculture and Environment 2017). The second largest afforestation is located in the municipality of Stallikon, and is part of the Buchenegg state forest (afforestation 2). This afforestation began in 1866/67 with 18 ha; since then around 100 ha of forest has been added (Weisz 1983) and the forest now covers an area of 970 ha (Office of Landscape, Agriculture and Environment 2017). The city of Winterthur purchased several farms in Etzberg from 1873 onwards, with the intention of creating the Hegi state forest (afforestation 9), which covers an area of 451 ha (Office of Landscape, Agriculture and Environment 2017). By expanding its forest area, the state aimed to establish a more sustainable use of its forest, including protection from natural hazards in steep terrain, as well as to receive revenues for the state budget (Schmid 1997).

The second most important driver of afforestation was compensatory afforestation, as prescribed by the forest law. The Swiss federal forest law, which came into force in 1876 to protect mountain forests, was extended to cover the entire nation in 1902 (Bürgi and Schuler 2003). In principle, deforestation from that point onwards was only granted if it was accompanied by compensatory afforestation measures. In cases where compensatory afforestation could not be implemented, an alternative form of payment was made to a cantonal fund, which supported voluntary afforestation (Weisz 1983). However, even before the national law was enforced, forest cover was protected by local laws and regulations which demanded compensational afforestation. An early instance of such compensation occurred at Kümberg (Turbenthal municipality, afforestation 3) and was demanded by the city of Winterthur as compensation for making a clearing of 21 ha at Eschenberg in 1873, in order to obtain land for industrial use. According to the local forest law of Zurich, compensatory afforestation in another location was mandatory (Madliger 1961). The municipality of Rafz afforested an area in 
Langenried (afforestation 4) as compensation for the clearcutting of an oak forest (deforestation 2) (Gemeinde Rafz 2013).

The third factor leading to afforestation was the need to establish forests as protection from natural hazards, such as landslides, flooding and avalanches. This factor also promoted the establishment of state forests (e.g., the Tössstock, afforestation 1 and 7), but it was also effective for other types of forest ownership, such as afforestation in the municipality of Adliswil (afforestation 8). This afforestation was the result of a decision by the Federal Council in 1901, which designated many areas for afforestation in order to establish protective forests (Krebs 1948).

Industrialization created job opportunities and increased labor costs, which made farming on less productive land less attractive and led to the afforestation of marginal land. Essentially, land owners realized that in these circumstances, forests promised higher returns than agriculture (Steiner 1953), triggering widespread small afforestation events from the 1860s onwards (Weisz 1983). Two examples from our case study are Elgg municipality (afforestation 5), which bought an area for afforestation in 1859 (Wirtschaftsplan Elgg 1883) and Rümlang municipality (afforestation 6 and 10), which drained its large wetland initially for the development of farmland, but afforested part of the land in around 1862 (Treichler 1996; Weisz 1983).

\subsubsection{Drivers of deforestation}

Industrialization not only changed the value of farmland compared to forest land, but also pushed many municipalities into financial problems, e.g., due to investments in railway lines that did not pay off. This was paralleled by a crisis in the agricultural sector. The financial debt of several municipalities was the main socioeconomic driver leading to deforestation in the first study period between 1850 and 1880. Rafz (deforestation 2), Embrach (deforestation 3), Weiach (5), Flaach (deforestation 8) and Oberstammheim (deforestation 9) municipalities all converted forest into agricultural land in order to sell the wood and to provide additional agricultural land for poor people (Gemeinde Rafz 2013; Krebs 1948; Stromer 1999; Weisz 1983; Wirtschaftsplan Oberstammheim 1872). Oberstammheim municipality (deforestation 9) was in debt due to the construction of a railway line (Wirtschaftsplan Oberstammheim 1872). Some of these 
municipalities invested part of the financial return from selling valuable timber into compensatory afforestation, as did Rafz municipality when it bought an area in the Langenried and afforested it as compensation for cutting down an oak forest (afforestation 4 and deforestation 2) (Gemeinde Rafz 2013). Another driver of deforestation in the first period between 1850 and 1880 was the correction of the river Töss, with the aim of preventing floods in Pfungen and Embrach municipalities (deforestation 7).

A second period of substantial deforestation took place between 1940 and 1970. During World War II, about 1,246 ha of forest were cleared in the Canton of Zurich, with no compensatory afforestation, in order to increase the availability of agricultural land so that Switzerland had enough food to be self-sufficient and to provide more wood to meet increased demand (Bürgi and Schuler 2003; Weisz 1983). The deforestation events in Embrach and Rorbas municipalities were consequences of this endeavor (deforestation 2). Another major driver was the development of infrastructure, the most prominent result of which was the largest deforestation event of the whole 150-year study period. 162 ha were deforested in the municipalities of Rümlang, Kloten and Oberglatt (deforestation 1) due to the construction of Zurich airport. Part of this area had just been afforested shortly before, i.e., between 1850 and 1910 (afforestation 6 and 10). In total, 270 ha of forest were cut down in this region for the construction of the airport (Weisz 1983). A second major deforestation event was caused by the construction of a new highway in the early 1960s (deforestation 4). The original plan, which was to build the road close to housing areas, was rejected by residents in the municipalities of Horgen and Oberrieden. As a result, the highway route was moved into forested area because the municipalities favored the conversion of forest areas in order to protect the quiet living environments of their residents. The clear cutting of 45 ha took place in the winters of 1959/1960 and 1960/1961 (Gattiker 1978). 


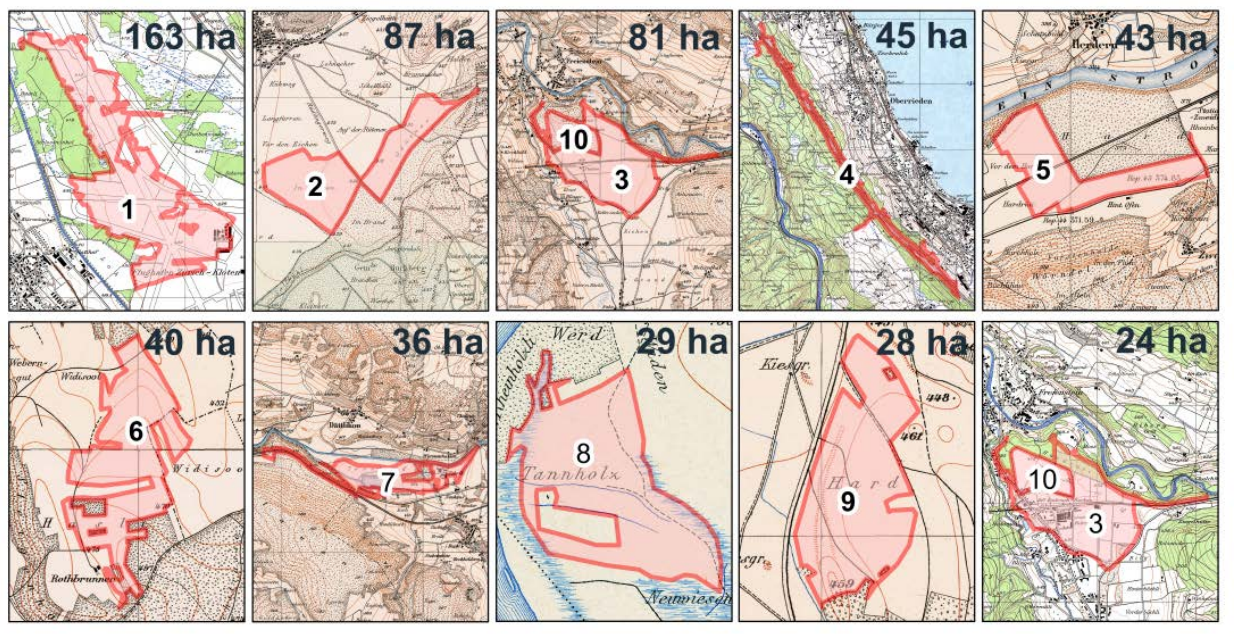

\section{Deforestation}
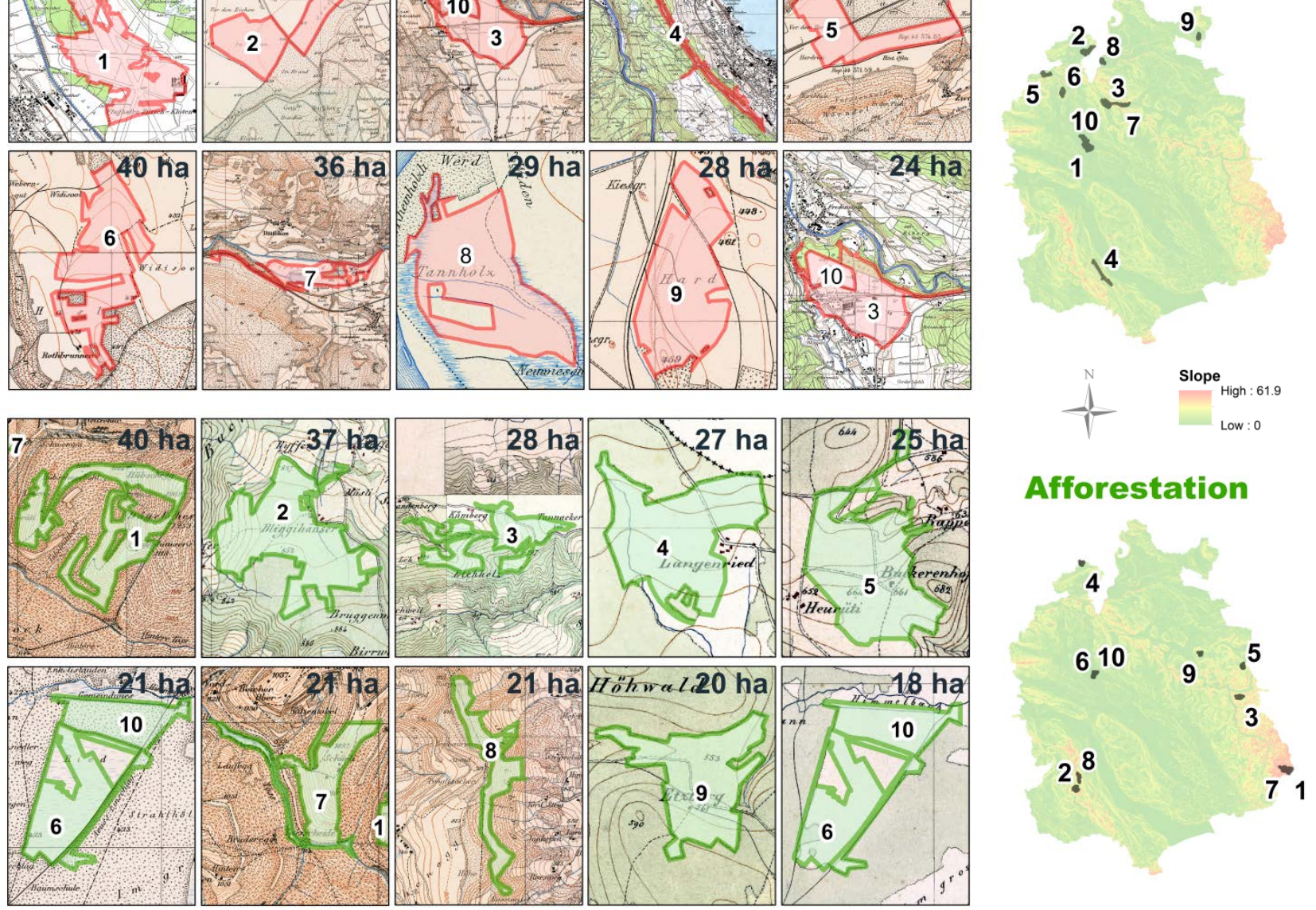

Fig. 6: The 10 largest deforestation and afforestation events in Canton Zurich between 1850 and 2000, ranked by size.

\subsubsection{Chains of drivers of forest cover change}

The identified drivers of deforestation and afforestation encompass technological, cultural, political, socioeconomic and natural factors, and were arranged in causal chains to provide a synoptic picture of their interplay (Fig. 7). Modernization is at the center of many of the changes observed, whether this is expressed by growing industry and the expansion of infrastructure, or more directly by changes in forest management. From the early $19^{\text {th }}$ century onwards, forest management in Switzerland became increasingly modernized and more based in science in order to increase efficiency, protection and sustainability (chain: modernization - forest management - protection function - afforestation). These changes included the expansion of state forests, which was the most frequent driver of afforestation in the Canton of Zurich. One of the main drivers of deforestation was municipal debt, which triggered a substantial amount 
of deforestation in order to generate income from selling timber (chain: income - timber deforestation). World War II brought about an increased need for local food production, resulting in the clearing of forests to extend the land available for agricultural production, while simultaneously providing timber which was also in high demand (chain: WWII - food - land for agriculture - deforestation; WWII - timber - deforestation). New infrastructure also caused a significant amount of deforestation if, e.g., new railroad tracks, roads or power lines ended up cutting through forest areas (chain: infrastructure - deforestation). In Fig. 7, we present all of the identified drivers and chains based on the conducted literature and historical document analysis. As each driver can belong to multiple chains, a chain may start from any of the drivers presented here, and not necessarily from the most significant ones, e.g., modernization or WWII.

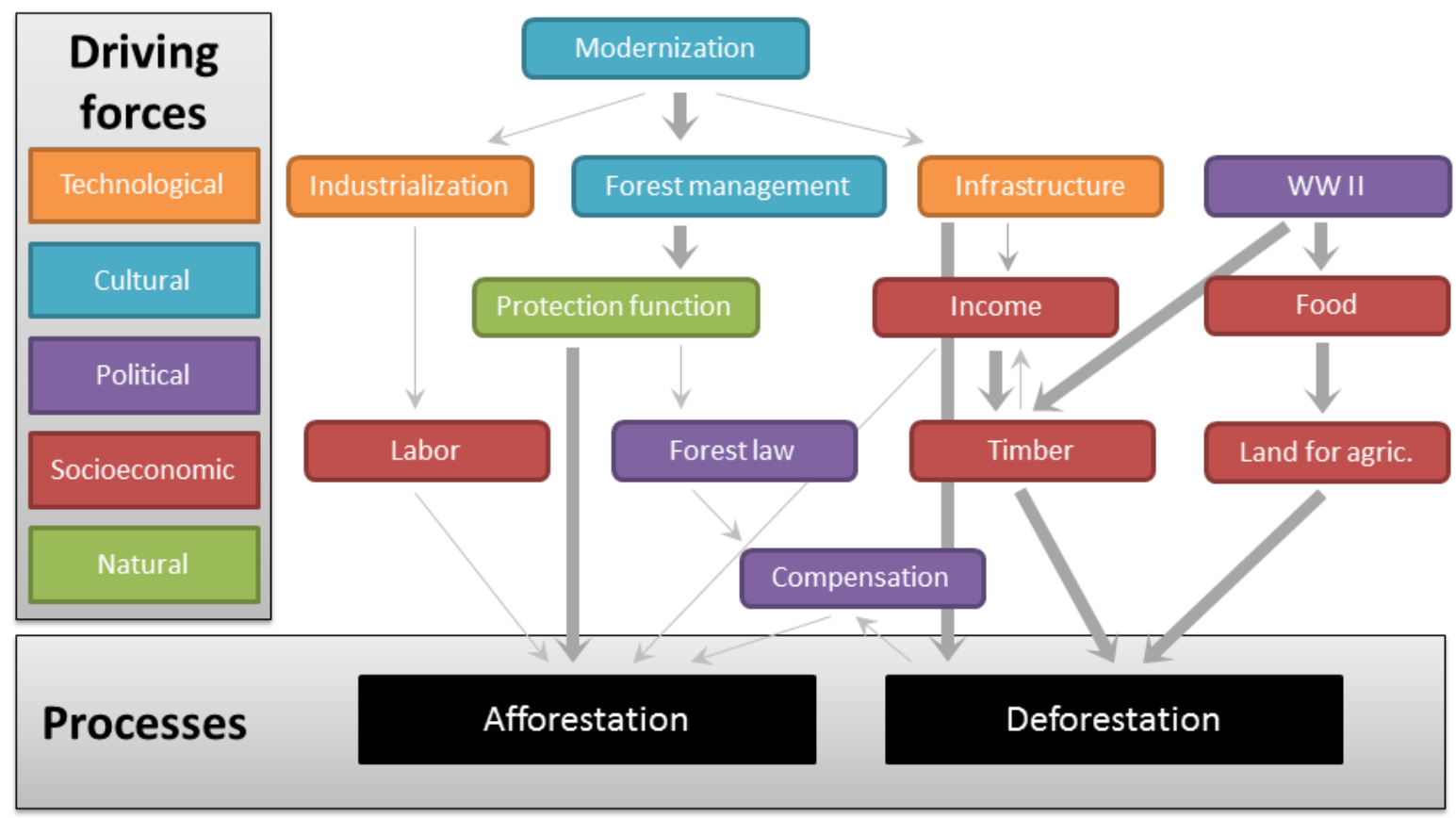

Fig. 7: The driving forces of forest cover change identified in the qualitative assessment are summarized and presented in chains. The drivers fall into the five categories technological, cultural, political, socioeconomic and natural drivers. The most frequent drivers, respectively chains, of afforestation and deforestation are indicated by thicker arrows and explained in more detail in the section 3.2.3. 


\subsubsection{Drivers of persistence}

The main factor fostering the persistence of overall forest cover were legal measures, i.e., the Forest Police Law, which came into effect in 1876, and its predecessors. These legal measures prohibited deforestation in general, resulting in a large amount of continuously forested area. Moreover, they enforced compensatory replacement afforestation (Angst 2012), resulting in the strong persistence of total forest cover. 


\section{Discussion}

\subsection{Strong persistence and minor changes of forest cover over the centuries}

About $80 \%$ of the forest cover in the Canton of Zurich in the year 2000 has been continuously forested over the last 150 years. This strong persistence stands in contrast to other regions in Europe, which have experienced a more substantial turnover in forest cover. For example, in Flanders in northern Belgium, only $16 \%$ of the forest cover had been continuously forested over a 225-year period up to the year 2000 (De Keersmaeker et al. 2015). The high persistence of forest cover shown in the Swiss lowlands also stands in contrast to the development of forest cover in the mountain areas of Switzerland, in which forest cover has increased strongly during the same period of time (Loran et al. 2017; Gellrich et al. 2007), thus resulting in a smaller proportion of continuous forest cover.

The strong persistence of net forest cover is supported by the results of our fragmentation analysis, which revealed the persistence of the shape complexity of forests over the whole study period. This identified shape complexity was based on the FRAC metric, which enables the quantification of spatial aggregation independent of habitat area and landscape grain size (Neel et al. 2004). Its insensitivity to variation in habitat abundance (Wang et al. 2014) made it a suitable metric for comparing fragmentation in forest cover over time.

While the net change in forest cover in the Canton of Zurich was minor, with a net gain of 88 ha between 1664 and 2000 - corresponding to an increase of $0.2 \%$ in 336 years - the gross change results depict the actual forest cover dynamics. Therefore, by only accounting for net changes, rather than gross changes, this leads to a serious underestimation of changes in forest cover. This is in line with the findings of Fuchs et al. (2014), who analyzed historic land change in Europe. In this study too, the full effects of land use and cover changes on, e.g., carbon emissions, are not detectable in the net changes (Calle et al. 2016; Fuchs et al. 2016; Wilkenskjeld et al. 2014). 


\subsection{Challenges of the methodological approaches}

The forest cover analysis is based on historical and contemporary maps, which were all drawn in different centuries. The first methodological challenge was therefore to compare maps of differing map quality, as measurement methods have become more accurate over time. A further challenge was the lack of definition of forest cover. Survey instructions did not provide the topographer with any details or guidelines on how they should identify forested areas in the field. Thus, forest assignment in the map was largely a matter of subjective decision-making by the topographer (Leyk 2005). A detailed assessment of the comparability of the maps used in this study was carried out by Loran et al. (2018), the result of which was that the oldest map by Gyger had to be excluded from most of the spatially explicit forest cover calculations due to its strong distortion and differences in the level of generalization of landscape elements. Still, the authors decided to use the Gyger map as a basis for calculating the total forest cover in 1664, which is a spatially independent result and valuable information in terms of understanding the long-term change in forest cover.

Two common approaches, i.e., quantitative or qualitative, can be used to determine the factors driving forest change and persistence. A well-established quantitative approach for assessing the complex interplay between driving forces and landscape change are empirical land-use change models (Plieninger et al. 2015; Rounsevell et al. 2012). Models such as these can enhance our understanding of the drivers of change by offering a simplified understanding of complex system functioning. These models usually focus on the prediction of general patterns and trends on regional or global scales, but are not designed to address dynamics on a local scale due to a lack of local data of sufficient quality to facilitate comparison over larger areas (Verburg et al. 2013). At a local level, the qualitative approach (e.g., expert interviews, literature analysis and the analysis of historical documents) is common in order to explore the driving forces behind forest cover change (e.g., Bürgi et al. 2015; Gimmi et al. 2009; Hersperger and Burgi 2009; Santruckova et al. 2015; Schneeberger et al. 2007). This approach is especially valuable for the detection of indirect drivers, which are not usually measured and thus cannot be captured by quantitative models. The downside of the qualitative approach is that the scope of the study is limited to a rather small area, as it is very time-consuming. Therefore, in this 
study, we only focus on major changes in forest cover. Causal chains of drivers were built based on the literature and on historical document analysis in order to understand deforestation and afforestation events in the Canton of Zurich. The procedure is largely in line with causal historical explanations, such as Abductive Causal Eventism (ACE), as proposed by Walters (2017). ACE 'is a form of causal-historical analysis that entails constructing causal histories of interrelated social and/or biophysical events backward in time and outward or inward in space through a process of eliminative inference and reasoning from effects to causes, called abduction' (Walters 2017: 608). However, further investigations will be needed to fully exploit the possibilities of such approaches for land change science and, specifically, the analysis of driving forces.

\subsection{Drivers leading to persistence and change in forest cover over the centuries}

The Canton of Zurich is the most densely populated canton in Switzerland with soil conditions facilitating a generally very intensive and thus competitive agricultural system. The development of forest cover in the lowlands, therefore, stands in contrast to forest dynamics in the alpine regions of Switzerland, which show a significant increase in forest cover over the last 150 years (Loran et al. 2016; Gellrich 2006). Forest cover is increasing in many mountainous regions across the globe (e.g., Lambin and Meyfroidt 2011; Melendez-Pastor et al. 2014; Munteanu et al. 2014; Stoate et al. 2009), mainly as a consequence of agricultural abandonment. In this study, land abandonment was not a relevant driver of the major changes in forest cover due to the overall high suitability of soils for agriculture. Still, it may have taken place on a comparatively limited scale, especially in more remote areas. Instead, the largest afforestation events in the Canton of Zurich were triggered by the development of state forest during the first two study periods (1850 to 1880 and 1880 to 1910), which can be attributed to the modernization of the forestry sector, including the establishment of protective forests to reduce the risk of debris flow and flooding. Additional important drivers were compensatory afforestation as a result of the forest law, as well as industrialization, which also triggered afforestation. Overall, two types of crises, economic and political, triggered deforestation; this 
was only partly compensated. During the economic crisis of the second half of the $19^{\text {th }}$ century, when many municipalities were in deep debt, forest clearing was promoted in order to obtain income - in this period, forests were still referred to as municipal bank accounts. The political crisis of World War II was the main driver of deforestation during the period between 1940 and 1970, having a strong impact on forest cover throughout Switzerland (Bürgi and Schuler 2003). Both types of crisis were calamitous in nature (Antrop 2005), leaving less time for careful planning and a detailed impact assessment. These findings illustrate how a high level of political and socioeconomic stability translates to persistent forest cover. Effective law enforcement is based on a stable government pursuing long-term planning. Calamities (Antrop 2005), however, have been shown to leave long-lasting marks on the landscape (e.g., Bürgi et al. 2017).

\section{Conclusion}

Our results highlight the value of considering causal chains and the interconnections between driving forces, as opposed to merely identifying single factors. These empirical findings shed light on the causes of forest cover change and the relevance of a high degree of political and economic stability. Political and socioeconomic development had a strong impact on forest cover, but with no clear tendency toward either deforestation or afforestation. Times of political instability, as well as socioeconomic poverty and liabilities, triggered large deforestation events. On the other hand, they also led to large afforestation projects. Understanding the strong relevance of political and socioeconomic developments on forest cover provides the opportunity to shape forest cover changes in a sustainable manner by applying appropriate political and economic measures. With this study, we underpin the value of focusing research on areas in which land use is more persistent, as this can enhance our knowledge on factors leading to the stabilization of landscapes (Lieskovský and Bürgi 2017). This is highly relevant for the regulation of undesirable land use change in our rapidly changing world. 


\section{References}

Amt für Landschaft und Natur (2017) Züricher Wald. Zahlen und Fakten. Access: http://www.aln.zh.ch/internet/baudirektion/aln/de/wald/zuercher_wald/zahlen_fakten. html

Andrén H (1994) Effects of Habitat Fragmentation on Birds and Mammals in Landscapes with Different Proportions of Suitable Habitat: A Review Oikos 71:355-366

Angst M (2012) Integration of Nature Protection in Swiss Forest Policy

Antrop M (2005) Why landscapes of the past are important for the future Landsc Urban Plan 70:21-34 doi:10.1016/j.landurbplan.2003.10.002

Baumann M, Kuemmerle T, Elbakidze M, Ozdogan M, Radeloff VC, Keuler NS, Prishchepov AV, Kruhlov I, Hostert P (2011) Patterns and drivers of post-socialist farmland abandonment in Western Ukraine. Land Use Policy 28:552-562 doi:10.1016/j.landusepol.2010.11.003

Brandt J, Primdahl J, Reenberg A (1999) Rural land-use and landscape dynamics - analysis of 'driving forces' in space and time. In: Krönert R, Baudry J, Bowler I, Reenberg A (eds) Land-use changes and their environmental impact in rural areas in Europe. Unesco. (Man and the Biosphere Series; No. 24), Paris

Bürgi M (1999) A case study of forest change in the Swiss lowlands Landscape Ecology 14:567575 doi:10.1023/a:1008168209725

Bürgi M, Hersperger AM, Schneeberger N (2004) Driving forces of landscape change - current and new directions Landscape Ecology 19:857-868 doi:10.1007/s10980-004-0245-8

Bürgi M, Ostlund L, Mladenoff DJ (2017) Legacy Effects of Human Land Use: Ecosystems as Time-Lagged Systems Ecosystems 20:94-103 doi:10.1007/s10021-016-0051-6

Bürgi M, Salzmann D, Gimmi U (2015) 264 years of change and persistence in an agrarian landscape: A case study from the Swiss lowlands Landscape Ecology 30:1321-1333 doi:10.1007/s10980-015-0189-1

Bürgi M, Schuler A (2003) Driving forces of forest management-an analysis of regeneration practices in the forests of the Swiss Central Plateau during the 19th and 20th century Forest Ecology and Management 176:173-183 doi:http://dx.doi.org/10.1016/S03781127(02)00270-0

Calle L, Canadell JG, Patra P, Ciais P, Ichii K, Tian H, Kondo M, Piao S, Arneth A, Harper AB, Ito A, Kato E, Koven C, Sitch S, Stocker BD, Vivoy N, Wiltshire A, Zaehle S, Poulter B (2016) Regional carbon fluxes from land use and land cover change in Asia, 1980-2009 Environmental Research Letters 11:074011 doi:10.1088/1748-9326/11/7/074011

Cunningham SC, Mac Nally R, Baker PJ, Cavagnaro TR, Beringer J, Thomson JR, Thompson RM (2015) Balancing the environmental benefits of reforestation in agricultural regions Perspectives in Plant Ecology, Evolution and Systematics 17:301-317 doi:10.1016/j.ppees.2015.06.001

De Keersmaeker L, Onkelinx T, De Vos B, Rogiers N, Vandekerkhove K, Thomaes A, De Schrijver A, Hermy M, Verheyen K (2015) The analysis of spatio-temporal forest changes (17752000) in Flanders (northern Belgium) indicates habitat-specific levels of fragmentation and area loss Landscape Ecology 30:247-259 doi:10.1007/s10980-014-0119-7 
Efroymson RA, Kline KL, Angelsen A, Verburg PH, Dale VH, Langeveld JWA, McBride A (2016) A causal analysis framework for land-use change and the potential role of bioenergy policy Land Use Policy 59:516-527 doi:10.1016/j.landusepol.2016.09.009

FAO - Food and Agricultural Organization (2016) State of the World's Forests 2016. Forests and agriculture: land-use challenges and opportunities. Rome

Foley JA, DeFries R, Asner GP, Barford C, Bonan G, Carpenter SR, Chapin FS, Coe MT, Daily GC, Gibbs HK, Helkowski JH, Holloway T, Howard EA, Kucharik CJ, Monfreda C, Patz JA, Prentice IC, Ramankutty N, Snyder PK (2005) Global Consequences of Land Use Science 309:570-574 doi:10.1126/science.1111772

Foster DR, Motzkin G, Slater B (1998) Land-Use History as Long-Term Broad-Scale Disturbance: Regional Forest Dynamics in Central New England Ecosystems 1:96-119

Fuchs R, Herold M, Verburg PH, Clevers JG, Eberle J (2014) Gross changes in reconstructions of historic land cover/use for Europe between 1900 and 2010 Global Change Biology 21:299-313 doi:10.1111/gcb.12714

Fuchs R, Schulp CJ, Hengeveld GM, Verburg PH, Clevers JG, Schelhaas MJ, Herold M (2016) Assessing the influence of historic net and gross land changes on the carbon fluxes of Europe Global Change Biology 22:2526-2539 doi:10.1111/gcb.13191

Gattiker E (1978) Die Geschichte unseres Gemeindewaldes. In: Horgner Jahrheft 1978. Geist HJ, Lambin EF (2002) Proximate Causes and Underlying Driving Forces of Tropical DeforestationTropical forests are disappearing as the result of many pressures, both local and regional, acting in various combinations in different geographical locations BioScience 52:143-150 doi:10.1641/0006-3568(2002)052[0143:PCAUDF]2.0.CO;2

Gellrich M, Baur P, Koch B, Zimmermann NE (2007) Agricultural land abandonment and natural forest re-growth in the Swiss mountains: A spatially explicit economic analysis Agriculture, Ecosystems \& Environment 118:93-108 doi:10.1016/j.agee.2006.05.001

Gellrich M, Zimmermann NE (2007) Investigating the regional-scale pattern of agricultural land abandonment in the Swiss mountains: A spatial statistical modelling approach Landsc Urban Plan 79:65-76 doi:10.1016/j.landurbplan.2006.03.004

Gimmi U, Wolf A, Bürgi M, Scherstjanoi M, Bugmann H (2009) Quantifying disturbance effects on vegetation carbon pools in mountain forests based on historical data Regional Environmental Change 9:121-130 doi:10.1007/s10113-008-0071-7

Grosjean G (1996) Geschichte der Kartographie. Geographica Bernensia, Bern. doi:10.4480/GB2013.U8

Hansen MC, Potapov PV, Moore R, Hancher M, Turubanova SA, Tyukavina A, Thau D, Stehman SV, Goetz SJ, Loveland TR, Kommareddy A, Egorov A, Chini L, Justice CO, Townshend JR (2013) High-resolution global maps of 21st-century forest cover change Science 342:850853 doi:10.1126/science.1244693

Hersperger AM, Burgi M (2009) Going beyond landscape change description: Quantifying the importance of driving forces of landscape change in a Central Europe case study Land Use Policy 26:640-648 doi:10.1016/j.landusepol.2008.08.015

Hersperger AM, Bürgi M (2007) Driving Forces of Landscape Change in The Urbanizing Limmat Valley, Switzerland. In: Koomen E, Stillwell J, Bakema A, Scholten H (eds) Modelling LandUse Change, vol 90. The GeoJournal Library. Springer Netherlands, pp 45-60. doi:10.1007/978-1-4020-5648-2_3 
Hu X, Wu C, Hong W, Qiu R, Li J, Hong T (2014) Forest cover change and its drivers in the upstream area of the Minjiang River, China Ecological Indicators 46:121-128 doi:10.1016/j.ecolind.2014.06.015

Imhof E (2007) Unsere Landkarten und ihre weitere Entwicklung. Zeitschrift für Vermessungswesen und Kulturtechnik. Buchdruckerei Winterthur.

Jaeger JAG, Schwarz-von Raumer HG, Esswein H, Müller M, Schmidt-Lüttmann M (2007) Time Series of Landscape Fragmentation Caused by Transportation Infrastructure and Urban Development: A Case Study from Baden-Württemberg, Germany Ecol Soc 12:22

Kaim D, Kozak J, Kolecka N, Ziółkowska E, Ostafin K, Ostapowicz K, Gimmi U, Munteanu C, Radeloff VC (2016) Broad scale forest cover reconstruction from historical topographic maps. Applied Geography 67:39-48 doi:http://dx.doi.org/10.1016/j.apgeog.2015.12.003

Kaplan JO, Krumhardt KM, Zimmermann N (2009) The prehistoric and preindustrial deforestation of Europe Quaternary Science Reviews 28:3016-3034 doi:10.1016/j.quascirev.2009.09.028

Kleemann J, Baysal G, Bulley HNN, Furst C (2017) Assessing driving forces of land use and land cover change by a mixed-method approach in north-eastern Ghana, West Africa. J Environ Manage 196:411-442 doi:10.1016/j.jenvman.2017.01.053

Kozak J, Estreguil C, Troll M (2007) Forest cover changes in the northern Carpathians in the 20th century: a slow transition Journal of Land Use Science 2:127-146 doi:10.1080/17474230701218244

Krauss J, Bommarco R, Guardiola M, Heikkinen RK, Helm A, Kuussaari M, Lindborg R, Ockinger E, Partel M, Pino J, Poyry J, Raatikainen KM, Sang A, Stefanescu C, Teder T, Zobel M, Steffan-Dewenter I (2010) Habitat fragmentation causes immediate and time-delayed biodiversity loss at different trophic levels. Ecology Letters 13:597-605 doi:10.1111/j.1461-0248.2010.01457.x

Krebs E (1948) Die Waldungen der Albis- und Zimmerbergkette. Winterthur, Kommissionsverlag der Gen. Buchh, p 329.

Lambin EF, Meyfroidt P (2011) Global land use change, economic globalization, and the looming land scarcity. Proceedings of the National Academy of Sciences of the United States of America 108:3465-3472 doi:10.1073/pnas.1100480108

Leyk S (2005) Computing the Past - Utilizing Historical Data Sources for Map-Based Retrospective Landscape Research. Dissertation, University of Zürich

Lieskovský J, Bürgi M (2017) Persistence in cultural landscapes: a pan-European analysis Regional Environmental Change doi:10.1007/s10113-017-1192-7

Liu J, Hull V, Moran E, Nagendra H, Swaffield SR, Turner BL, II (2014) Applications of the telecoupling framework to land-change science. In: Rethinking Global Land Use in an Urban Era, pp 119-140

Llausàs A, Nogué J (2012) Indicators of landscape fragmentation: The case for combining ecological indices and the perceptive approach Ecological Indicators 15:85-91 doi:http://dx.doi.org/10.1016/j.ecolind.2011.08.016

Loran C, Ginzler C, Bürgi M (2016) Evaluating forest transition based on a multi-scale approach: forest area dynamics in Switzerland 1850-2000 Regional Environmental Change 16:1807-1818 doi:10.1007/s10113-015-0911-1 
Loran C, Haegi S, Ginzler C (2018) Comparing historical and contemporary topographic maps - A methodological framework for a cartographic map comparison applied to Swiss maps. International Journal of Geographical Information Science 32 doi.org/10.1080/13658816.2018.1482553

Loran C, Munteanu C, Verburg PH, Schmatz DR, Bürgi M, Zimmermann NE (2017) Long-term change in drivers of forest cover expansion: an analysis for Switzerland (1850-2000) Regional Environmental Change:1-13 doi:10.1007/s10113-017-1148-y

Matthews E, Payne R, Rohweder M, Murray S (2000) Pilot analysis of global ecosystems. Forest ecosystems. World Resources Institute, Washington DC

Melendez-Pastor I, Hernández El, Navarro-Pedreño J, Gómez I (2014) Socioeconomic factors influencing land cover changes in rural areas: The case of the Sierra de Albarracín (Spain) Applied Geography 52:34-45 doi:http://dx.doi.org/10.1016/j.apgeog.2014.04.013

Meyfroidt P (2015) Approaches and terminology for causal analysis in land systems science Journal of Land Use Science:1-27 doi:10.1080/1747423x.2015.1117530

Meyfroidt P, Lambin EF (2011) Global Forest Transition: Prospects for an End to Deforestation Annual Review of Environment and Resources 36:343-371 doi:10.1146/annurev-environ$090710-143732$

Munteanu C, Kuemmerle T, Boltiziar M, Butsic V, Gimmi U, Lúboš H, Kaim D, Király G, KonkolyGyuró É, Kozak J, Lieskovský J, Mojses M, Müller D, Ostafin K, Ostapowicz K, Shandra O, Štych P, Walker S, Radeloff VC (2014) Forest and agricultural land change in the Carpathian region-A meta-analysis of long-term patterns and drivers of change. Land Use Policy 38:685-697 doi:10.1016/j.landusepol.2014.01.012

Munteanu C, Kuemmerle T, Keuler NS, Müller D, Balázs P, Dobosz M, Griffiths P, Halada L, Kaim D, Király G, Konkoly-Gyuró É, Kozak J, Lieskovsky J, Ostafin K, Ostapowicz K, Shandra O, Radeloff VC (2015) Legacies of 19th century land use shape contemporary forest cover. Global Environmental Change 34:83-94 doi:10.1016/j.gloenvcha.2015.06.015

Murcia C (1995) Edge effects in fragmented forests: implications for conservation. Trends Ecol. Evol. 10:58-62.

Plieninger T, Kizos T, Bieling C, Le Dû-Blayo L, Budniok M-A, Bürgi M, Crumley CL, Girod G, Howard P, Kolen J, Kuemmerle T, Milcinski G, Palang H, Trommler K, Verburg PH (2015) Exploring ecosystem-change and society through a landscape lens: recent progress in European landscape research. Ecol Soc 20 doi:10.5751/es-07443-200205

Plieninger T, Draux H, Fagerholm N, Bieling C, Bürgi M, Kizos T, Kuemmerle T, Primdahl J, Verburg PH (2016) The driving forces of landscape change in Europe: A systematic review of the evidence. Land Use Policy 57:204-214

doi:10.1016/j.landusepol.2016.04.040

Price B, Kaim D, Szwagrzyk M, Ostapowicz K, Kolecka N, Schmatz DR, Wypych A, Kozak J (2016) Legacies, socio-economic and biophysical processes and drivers: the case of future forest cover expansion in the Polish Carpathians and Swiss Alps. Regional Environmental Change:1-13 doi:10.1007/s10113-016-1079-z

Regos A, Ninyerola M, More G, Pons X (2015) Linking land cover dynamics with driving forces in mountain landscape of the Northwestern Iberian Peninsula. Int J Appl Earth Obs Geoinf 38:1-14 doi:10.1016/j.jag.2014.11.010 
Rhemtulla JM, Mladenoff DJ, Clayton MK (2009) Legacies of historical land use on regional forest composition and structure in Wisconsin, USA (mid-1800s-1930s-2000s) Ecological Applications 19:1061-1078 doi:10.1890/08-1453.1

Rounsevell MDA, Pedroli B, Erb K-H, Gramberger M, Busck AG, Haberl H, Kristensen S, Kuemmerle T, Lavorel S, Lindner M, Lotze-Campen H, Metzger MJ, Murray-Rust D, Popp A, Pérez-Soba M, Reenberg A, Vadineanu A, Verburg PH, Wolfslehner B (2012) Challenges for land system science. Land Use Policy 29:899-910 doi:10.1016/j.landusepol.2012.01.007

Rutherford GN (2006) The use of land-use statistics to investigate large-scale successional processes. Dissertation, Swiss Federal Institute of Technology Zurich

Santruckova M, Dostalek J, Demkova K (2015) Assessing long-term spatial changes of natural habitats using old maps and archival sources: a case study from Central Europe.

Biodiversity and Conservation 24:1899-1916 doi:10.1007/s10531-015-0912-x

Schneeberger N, Bürgi M, Hersperger AM, Ewald KC (2007) Driving forces and rates of landscape change as a promising combination for landscape change research-An application on the northern fringe of the Swiss Alps. Land Use Policy 24:349-361

doi:10.1016/j.landusepol.2006.04.003

Schmid H (1997) Die Entstehungsgeschichte der zürcherischen Staatswälder. Zeitschrift Zürcher Wald 2:12-17.

Serneels S, Lambin EF (2001) Proximate causes of land-use change in Narok District, Kenya: a spatial statistical model Agriculture, Ecosystems \& Environment 85:65-81 doi:http://dx.doi.org/10.1016/S0167-8809(01)00188-8

Skaloš J, Engstová B, Trpáková I, Šantrůčková M, Podrázský V (2011) Long-term changes in forest cover 1780-2007 in central Bohemia, Czech Republic European Journal of Forest Research 131:871-884 doi:10.1007/s10342-011-0560-y

Steiner $H$ (1954) Pfungen. Ortsgeschichte und Heimatbuch. Winterthur.

Stoate C, Báldi A, Beja P, Boatman ND, Herzon I, van Doorn A, de Snoo GR, Rakosy L, Ramwell C (2009) Ecological impacts of early 21st century agricultural change in Europe - A review Journal of Environmental Management 91:22-46 doi:http://dx.doi.org/10.1016/j.jenvman.2009.07.005

Stromer M (1999) Geschichte der Gemeinde Embrach. Das 19. und 20. Jahrhundert.

Terres J-M, Scacchiafichi LN, Wania A, Ambar M, Anguiano E, Buckwell A, Coppola A, Gocht A, Källström HN, Pointereau P, Strijker D, Visek L, Vranken L, Zobena A (2015) Farmland abandonment in Europe: Identification of drivers and indicators, and development of a composite indicator of risk Land Use Policy 49:20-34 doi:10.1016/j.landusepol.2015.06.009

Treichler HP (1996) Rümlang ein Dorf mit Geschichte. Frauenfeld.

Verburg PH, Erb KH, Mertz O, Espindola G (2013) Land System Science: between global challenges and local realities Curr Opin Environ Sustain 5:433-437 doi:10.1016/j.cosust.2013.08.001

Wade TG, Riitters KH, Wickham JD, Bruce JK (2003) Distribution and Causes of Global Forest Fragmentation Conservation Ecology 7:7

Walser H (1896) Veränderungen der Erdoberfläche im Unkreis des Kantons Zürich seit der Mitte des 17. Jahrhunderts. Geographisches Institut der Universität Bern, Bern. 
Walters BB (2017) Explaining rural land use change and reforestation: A causal-historical approach Land Use Policy 67:608-624 doi:10.1016/j.landusepol.2017.07.008

Wang X, Blanchet FG, Koper N, Tatem A (2014) Measuring habitat fragmentation: An evaluation of landscape pattern metrics Methods in Ecology and Evolution 5:634-646 doi:10.1111/2041-210x.12198

Weisz L, Grossmann H, Krebs E, Ritzler K, Oldani C (1983) 650 Jahre zürcherische Forstgeschichte, Bd. 2. Zürich. $430 \mathrm{~S}$.

Wilkenskjeld S, Kloster S, Pongratz J, Raddatz T, Reick CH (2014) Comparing the influence of net and gross anthropogenic land-use and land-cover changes on the carbon cycle in the MPI-ESM Biogeosciences 11:4817-4828 doi:10.5194/bg-11-4817-2014

Wyder S (2006) Grenz-, Zehnten und Befestigungspläne des Zürcher Gebiets von Hans Conrad Gyger (1599-1674). Sonderheft Nr. 18 der Fachzeitschrift für Kartengeschichte. Catrographica Helvetica Murten 
Submitted to: European Journal of Forest Research

Persistence and change - Exploring the driving forces of long-term forest cover dynamics in the Swiss lowlands

Christin Loran ${ }^{a *}$, Felix Kienast $^{\mathrm{a}}$, Matthias Bürgi ${ }^{\mathrm{a}}$

Address:

${ }^{a}$ WSL Swiss Federal Institute for Forest, Snow and Landscape Research, Zürcherstrasse 111, 8903 Birmensdorf, Switzerland

*Corresponding author:

Tel: $\quad$ +41 447392817 (Phone)

Fax: $\quad+41447392215$ (FAX)

Mail: Christin.loran@wsl.ch 


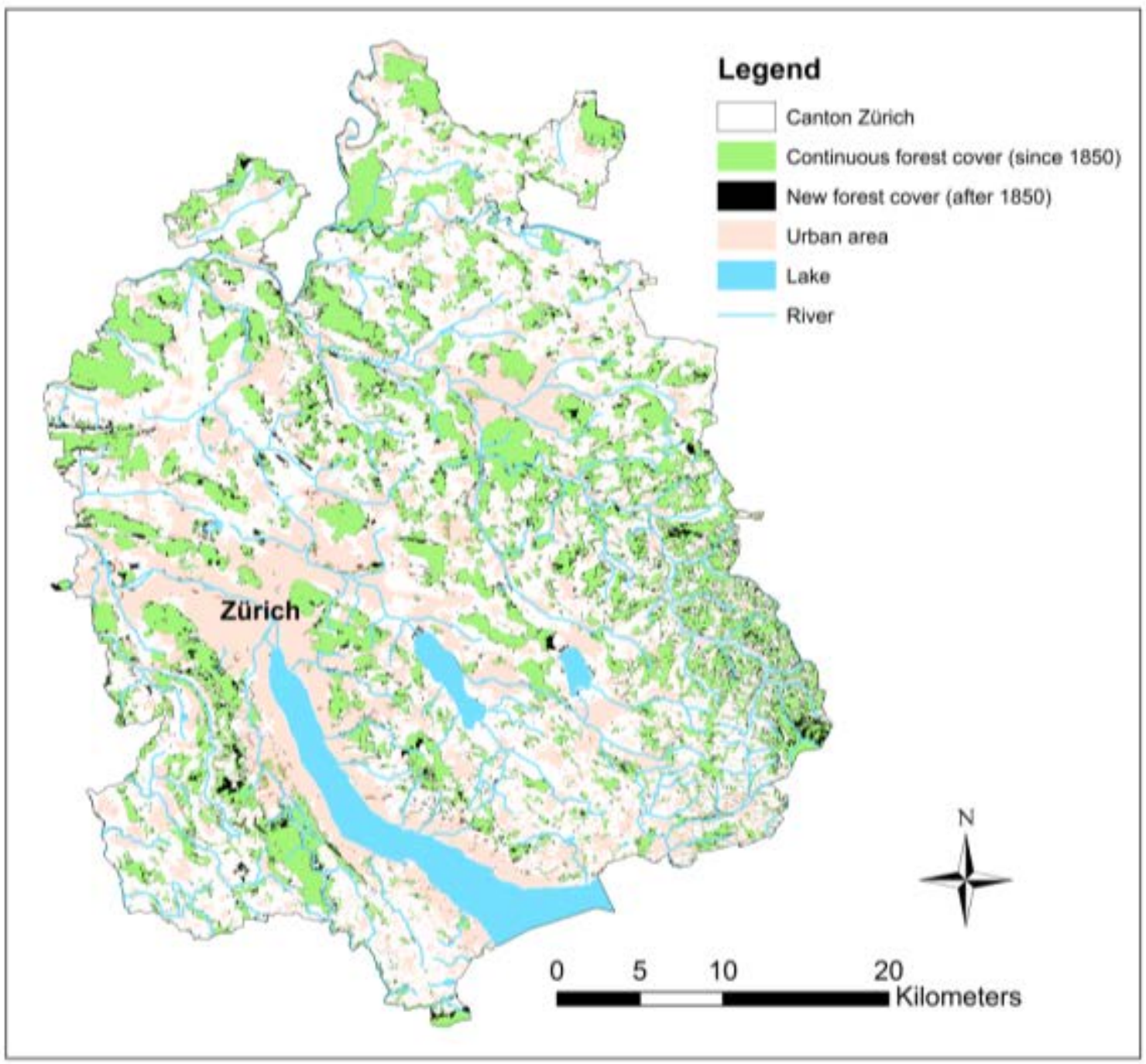

Fig. 3: New and continuous forest cover in Canton Zurich since 1850. In general new forest patches are found all over the canton, but major clusters are found especially east of lake Zurich and in the south-east towards the boarder of the canton.

Tab. 3: Forest cover and infrastructure (road and railway lines) within the forest patches.

\begin{tabular}{cccc}
\hline YEAR & Forest Cover $\left(\mathrm{km}^{2}\right)$ & Infrastructure $\left(\mathrm{km}^{2}\right)$ & Proportion of infrastructure (\%) \\
\hline 1850 & 526.67 & 1.94 & 0.37 \\
1880 & 499.48 & 1.88 & 0.38 \\
1910 & 501.74 & 2.49 & 0.50 \\
1940 & 498.25 & 2.66 & 0.53 \\
1970 & 477.32 & 3.51 & 0.74 \\
2000 & 506.78 & 4.69 & 0.93 \\
\hline
\end{tabular}

